\title{
Ecological studies in Alto Guadalquivir wetlands: a first step towards the application of conservation plans
}

\author{
Francisco Guerrero*; Gema Parra; Francisco Jiménez-Gómez; Carlos Salazar; \\ Raquel Jiménez-Melero; Andrea Galotti; Enrique García-Muñoz; Ma Lucía Lendínez \\ and Fernando Ortega
}

Departamento de Biología Animal, Biología Vegetal y Ecología. Facultad de Ciencias Experimentales. Universidad de Jaén. Campus de las Lagunillas s/n. E-23071 Jaén

*Corresponding author: fguerre@ujaen.es

\begin{abstract}
This paper reviews the most recent studies carried out in the Alto Guadalquivir wetlands. Data on wetland inventory and classification in typologies, faunal and floral community values are presented as well as the effects that agricultural pollutants have on some aquatic species. These results support the need for a correct wetland policy that allows for the conservation of these aquatic ecosystems.
\end{abstract}

Keywords: Natural wetlands, artificial wetlands, Alto Guadalquivir, agricultural impacts, conservation.

\section{RESUMEN}

Este trabajo revisa los estudios más recientes llevados a cabo en los humedales de la comarca del Alto Guadalquivir. Se presentan datos sobre el inventario de humedales y su clasificación en tipologías, los valores más relevantes de sus comunidades de flora y fauna y los efectos que ejercen los contaminantes agricolas sobre algunas especies. Estos resultados apoyan la necesidad de una correcta politica de humedales que permita la conservación de estos ecosistemas acuáticos.

Palabras clave: Humedales naturales, humedales artificiales, Alto Guadalquivir, impactos agrícolas, conservación.

\section{INTRODUCTION}

Wetlands are among the most important ecosystems on earth and constitute a major feature of the landscape in almost all parts of the world (Mitsch \& Gosselink, 2000). In Mediterranean landscapes, wetlands, as in other drylands, represent a broad variety of natural resources with environmental, social, and scientific values and play an important role in the maintenance of biological diversity (Williams, 1999). Despite their great intrinsic values, these ecosystems have been subjected to strong human influence (Naveh \& Lieberman, 1994), and are suffering an accelerating process of degradation leading to the disappearance of many of them (Hollis, 1995; Brinson \& Álvarez, 2002). Casado and Montes (1995) indicate that more than $60 \%$ of
Spanish wetlands have disappeared in the last 50 years and, in spite of the recent acceptance of the ecological importance of wetlands, this trend has not yet been reversed (Amezaga et al., 2002).

Andalusia presents rich ecological wetland diversity, including the rarest ecosystem in Western Europe (Molina et al., 2002), which represents one of the most important wetland districts in Spain. Inside this group, little is known about the extent and condition of the wetlands in the Alto Guadalquivir region. Thus, as a consequence of the lack of attention given to wetlands and the scarcity of limnological information, this paper reviews the recent studies carried out in the Alto Guadalquivir wetlands, in order to encourage the expansion of wetland policies beyond the identification and conservation of individual wetland sites. 


\section{STUDY AREA}

The Alto Guadalquivir region comprises the totality of the Jaén province and the eastern area of the Córdoba province, in southeastern Spain. This region covers the upper reaches of the Guadalquivir River Basin and encompasses a great environmental and physiographic diversity. The climate is Mediterranean, characterised by hot dry summers and cold dry winters, with mild humid springs and autumns. Another peculiarity is the existence of a high inter-annual variation in precipitation, with periods of wet or dry cycles. Agriculture, particularly olive plantations have been carried out for centuries in the area and currently constitute the major land use and the principal economic activity in the area.

\section{WETLAND INVENTORY AND CLASSIFICATION}

Wetland inventory and classification in typologies are necessary prior to carrying out limnological studies, in order to collect further management-oriented information, which can provide the basis for many important measures to conserve wetlands (Finlayson et al., 1999). The Alto Guadalquivir has been considered a poor wetlands region in the past, but recent studies have demonstrated the existence of a large number of aquatic ecosystems. The first results obtained showed the existence of at least 400 wetlands (see Ortega et al., 2003; Ortega et al., 2005; Guerrero et al., unpublished data). The data from this wetland inventory must be regarded as provi-
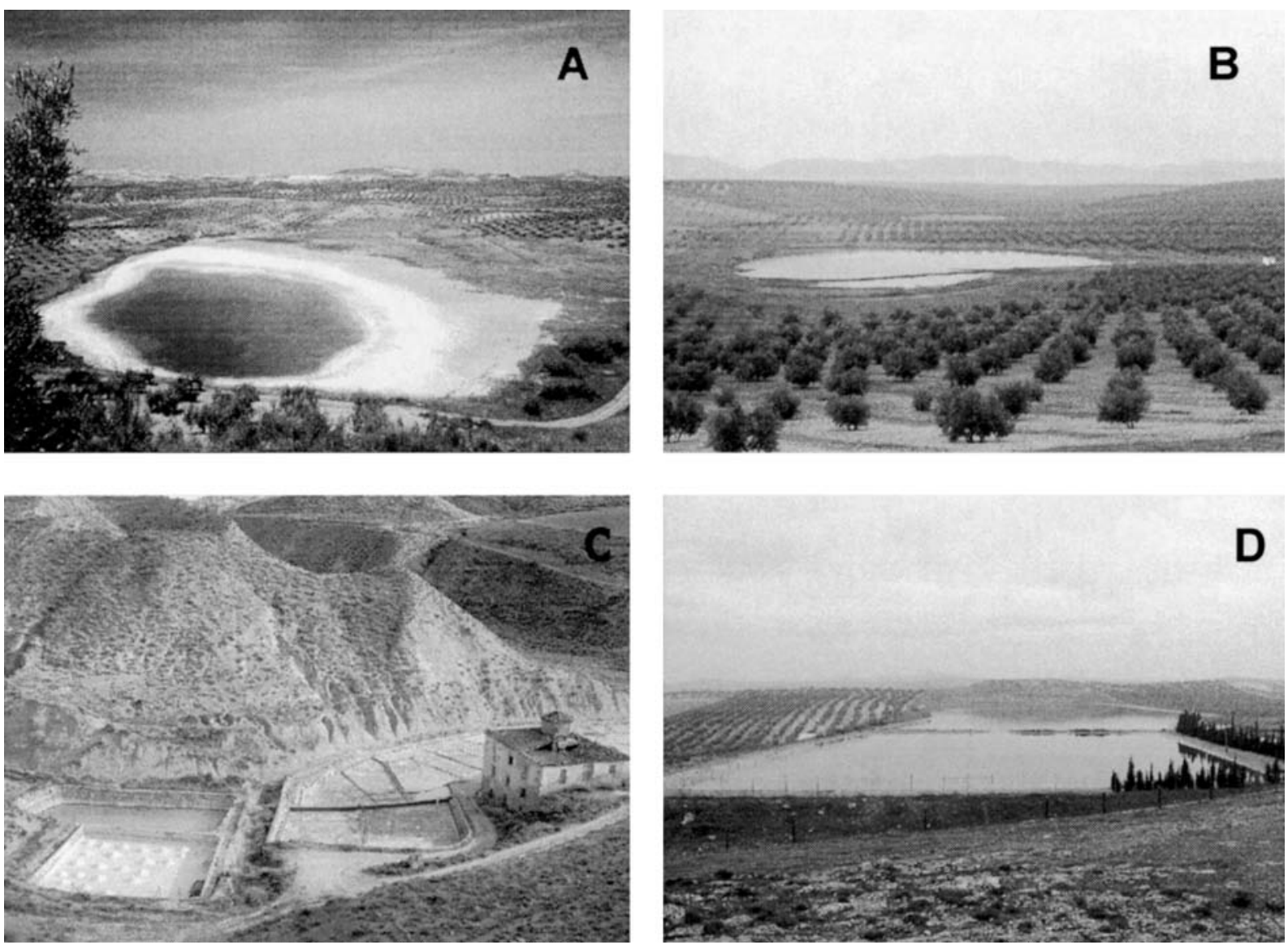

Figure 1. Four examples of wetlands in the Alto Guadalquivir region. A: Laguna Honda (natural wetland); B: Laguna de Brujuelo (natural wetland); C: Chillar salina (artificial wetland) and D: Torrequebradilla irrigation pond (artificial wetland). Cuatro ejemplos de humedales de la comarca del Alto Guadalquivir. A: Laguna Honda (humedal natural); B: Laguna de Brujuelo (humedal natural); C: Salina de Chillar (humedal artificial) y D: Balsa de Torrequebradilla (humedal artificial). 
sional, but it represents the first study based on field data, which provides a global view to the Alto Guadalquivir wetland conservation.

An initial classification allows us to divide the wetlands in two typologies: natural (around one hundred of them) and artificial wetlands (Fig. 1). Most of the natural wetlands are situated in endorheic basins and they are strongly dependent on the hydrological budget, so limnological and ecological characteristics have a large seasonal and interannual variability. The most common natural wetlands are temporary shallow lakes with a small surface area, especially "lagunas" or steppe lakes. Wetlands are not randomly distributed throughout the Alto Guadalquivir region and are situated between 250 and 1600 m.a.s.1. Three main areas (Campiña Norte, Campiña Sur, and La Loma), close to the Guadalquivir River, can be distinguished according to the number of wetlands, representing up to $75 \%$ of the total wetlands in the region. The rest of the wetlands are distributed in other six mountain areas (Sierra Morena, Sierra Sur, Sierra Mágina, El Condado, Sierra de Cazorla, and Sierra de Segura). In a second classification using a genetic-functional criterion, we detect the presence of other six wetlands categories. The predominant type in mountainous areas is karstic, and in the countryside areas the principal type is associated to calcareous-marl soils (Ortega et al., 2003).

Artificial wetlands are principally represented in the area by inland salinas (solar evaporation salinas) and irrigation ponds, anthropogenic ecosystems, which present also important scientific, social, and cultural values (we did not include reservoirs neither man-made pool for livestock use, which are abundant in Sierra Morena). The inventory of inland salinas numbers nearly one hundred, ranging in size from 0.1 to 4.5 ha. They are situated between 250 and 1050 m.a.s.1., and principally on the right side of the Guadalquivir River (Guerrero et al., 2004), because the origin of inland salinas is especially linked with Keuper facies areas. Inland salinas are classified, based on morphological and geographical criteria, in two typologies (Quesada, 1996): inland mountain salinas (situated normally above 600 m.a.s.l., with small dimensions) and inland countryside sali- nas (< 600 m.a.s.1., with a larger surface area situated across the riversides).

Irrigation ponds are the most recent artificial wetlands in Alto Guadalquivir and they have been proliferating in recent years as a consequence of the intensification of agricultural practices. Therefore, they are also more abundant in the areas close to the Guadalquivir River (Campiña Norte, Campiña Sur, and La Loma), in which olive agriculture predominate. We can distinguish two categories according to the existence of a sedimentation basin (Ortega et al., 2005); those containing this basin present a richer diversity. They are permanent wetlands and represent an important refuge for the flora and fauna during dry periods, when natural wetlands do not store water.

The most important human impacts affecting the Alto Guadalquivir wetlands are agricultural practices, including aquifer over-exploitation, tillage, drainage and dredging, and alteration of water regime (Ortega et al., 2003). These activities together with the economic death of inland salinas lead to a progressive abandonment and deterioration of both natural and artificial wetlands. As a result, many wetlands have disappeared and sometimes only some unidentifiable debris on the ground serves as a witness to their presence in the past.

\section{FLORA AND VEGETATION}

Wetlands comprise a marginal belt of phreatophytes and/or helophytes and an open-water area with different types of primary producers (i.e. submerged macrophytes). We studied these communities in both natural and artificial wetlands (see Ortega et al., 2001; Ortega \& Guerrero, 2003; Ortega et al., 2004a; Salazar et al., 2003) and the results obtained show the existence of a high floristic diversity.

A recent study performed on 140 Andalusian wetlands in 2004 (Ortega et al., unpublished data) demonstrated that the Alto Guadalquivir region is rich in species of submerged macrophytes, with the presence of 12 charophyte algae and 23 aquatic plants: 1 bryophyte, 1 pteridophyte and 21 angiosperms, which represent the $55 \%, 50 \%, 33 \%$ and $70 \%$ of the recorded 


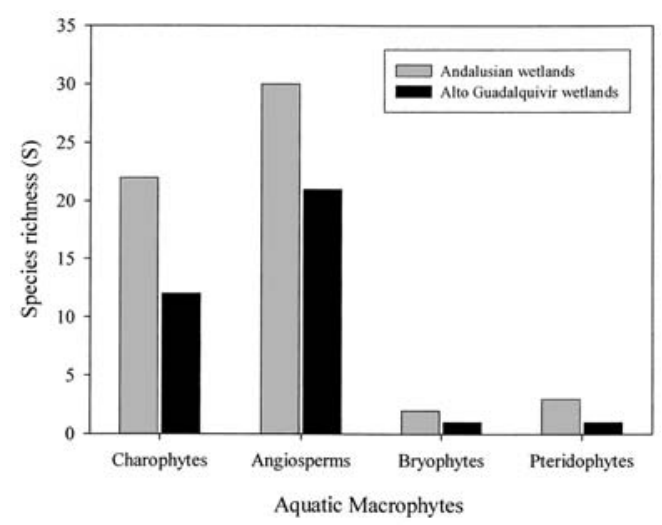

Figure 2. Macrophytes' species richness (charophytes, angiosperms, bryophytes and pteridophytes) in the Andalusia (grey) and Alto Guadalquivir (black) wetlands. Data from a study performed in 2004 (Ortega et al., unpublished data). Riqueza específica de macrófitos (carófitos, angiospermas, briófitos y pteridófitos) en humedales de Andalucía (gris) y de la comarca del Alto Guadalquivir (negro). Datos obtenidos de un estudio realizado en 2004 (Ortega et al., datos no publicados).

species in this study respectively (Fig. 2). The most significant submerged macrophyte species are the charophytes Chara connivens, Ch. fragilis, Ch. aspera, Ch. vulgaris longibracteata, Lamphrothamnium papulosum, Nitella flexilis and Tolypella hispanica; the aquatic angiosperms Althenia orientalis, Miriophyllum alterniflorum, Najas marina, Potamogeton pectinatus, P. natans, P. pusillus, Ranunculus peltatus, Ruppia drepanensis, R. maritima, Zannichellia contorta, Z. obtusifolia, Z. pedunculata and Z. peltata; and finally, the aquatic bryophyte Riella helicophylla, and the pteridophyte Isoetes setaceum. From the list mentioned above, Althenia orientalis and Zannichellia contorta are of national and regional interest, since they are included in the Red List of Spanish Vascular Flora (VV.AA., 2000), the Atlas and Red Data Book of Vascular Threatened Flora of Spain (Bañares et al., 2003) and the Red List of Vascular Flora of Andalusia (Cabezudo et al., 2005) under the IUCN threat category of vulnerable (VU), and Isoetes setaceum is included in the Red Data Book of Endangered Wild Flora of Andalusia (Blanca et al., 2000) with the same category. Furthermore, Zannichellia peltata and $Z$. pedunculata have recently been catalogued in the mentioned Andalusian Red List as vulnerable (VU), whilst Potamogeton natans, P. pusi- llus, Ruppia drepanensis and R. maritima appear as species with deficient data (DD). Finally, these species are included in three natural habitat types of community interest, and one of them is a priority type (coastal lagoons).

The studies on phreatophyte communities in natural and artificial wetlands show the presence of at least 175 taxa and 40 phytosociological associations, 26 of which are included in Annex I of Habitat Directive 92/43/EEC. We also detected the existence of at least 12 habitats of community interest, three of which are priority types (mediterranean salt steppes, mediterranean temporary ponds and inland salt meadows). The most significant phytocoenoses are perennial helophytic communities (Typho-Schoenoplectetum glauci, Acrocladio cuspidati-Eleocharitetum palustris, Bolboschoenetum maritimi), ephemeral helophytic vegetation (Preslio-Eryngietum corniculati, Damasonio alismae-Crypsietum aculeatae), halophilous riparian shrublands (Elymo repentis-Tamaricetum canariensis), and a great variety of halophilous pastures and grasslands: Polypogono maritimi-Hordeetum marini, Parapholido incurvae-Frankenietum pulverulentae subas. spergularietosum tangerinae, Suaedo splendentis-Salsoletum sodae, Polypogono maritimi-Centaurietum spicati, Suaedo splendentisSalicornietum patulae, Aeluropodo littoralisJuncetum subulati, including the remarkable association Limonio quesadensis-Lygeetum spar$t i$, endemic to the eastern Guadalquivir Basin (García-Fuentes et al., 2001). It is also important to note the presence of taxa such as Limonium quesadense, an endemic species included in the Red List of Spanish Vascular Flora, Atlas and Red Data Book of Vascular Threatened Flora of Spain and the Red List of Vascular Flora of Andalusia as an endangered species (EN), together with Puccinellia fasciculata, which is considered as a species with deficient data (DD) in the Red List of Spanish Vascular Flora.

\section{PLANKTON COMMUNITY}

Since knowing all wetlands is very difficult to attain, the studies on the plankton community in 
natural wetlands were reduced to Laguna Honda. This is a hypersaline ecosystem situated in an endorheic basin (south-western Jaén), whose origin is connected with karstic phenomena in gypsum and saline materials of the Trias (Castro et al., 2003). This saline lake provides excellent conditions for ecological studies because is characterised by fluctuations in water level at different time scales. Thus, environmental factors play a major role in shaping the plankton community, and consequently changes in the biological communities are related to physical and chemical characteristics. We outline the characteristics of the plankton community during two periods with different hydrological budgets and consequently different behaviour of the system. The low precipitations during a dry cycle (1994-95) caused the lake to dry in summer, with an increment of salinity. This is the principal factor controlling the dynamics of plankton community in these hypersaline ecosystems, with the present number of species tending to decline as total salt content increases (García \& Niell, 1993). As a consequence, plankton assemblages were very different between periods, with the dominance of the halotolerant pico-nanoplankton species $(\mathrm{Du}$ naliella viridis; Dunaliella salina; Tetraselmis apiculata; Hantzchia amphioxys; Oscillatoria lute $a$ and the dinoflagellate Gymnodinium excavatum) during the dry period (Guerrero \& Castro, 1997; López-González et al., 1998), and a considerable increase of phytoplankton species richness (Jiménez-Melero, unpublished data) during the rainy cycle (1998-99 and 200102), especially diatoms (i.e. Fragilaria capucina, Navicula cocconeiformis and Nitzschia reversa). The harpacticoid benthonic copepod Cletocamptus retrogressus together with turbellarian species and the ciliate Fabrea salina, were the most important zooplankton species during dry cycles (López-González et al., 1998). Zooplankton richness increased in the wet period, with new species of a more planktonic behaviour that were not collected during the previous cycle (Daphnia mediterranea; Moina salina; Alona sp.; Cyclops sp.; Arctodiaptomus salinus and Hexarthra fennica) (Castro, 2004;
Jiménez-Melero, unpublished data). As we can see, the plankton community responds with usual changes to a salinity gradient occurring during a hydrological cycle and during a large inter-annual time scale. During rainy years, the plankton community ranges from limnogenic $\alpha$-hypersaline to $\beta$-hypersaline type, whereas as the salinity increases the community changes towards a community similar to that of the $\gamma$-type and $\delta$-type waters (sensu Por, 1980).

The plankton community of artificial wetlands (inland salinas) is fundamentally represented by pico-nanoplanktonic species and by the anostracean crustacean Artemia sp., which are mainly present in the water accumulation basins of these ecosystems. In order to measure biomass, abundance, and the functional composition of the pico-nanoplankton community, scarcely studied in this type of ecosystems, we have applied automated analyses techniques such as flow cytometry and microscopic image analysis. These techniques allow for a fast and objective characterization of heterotrophic and phototrophic components of this biota, and permit the link between single cell properties and community organization (Platt, 1989). In a study of about thirty inland salinas, the phytoplankton community showed densities ranging between 1 and 1000 cells $/ \mathrm{ml}$, mostly small flagellates and by benthic diatoms, such as Nitzschia spp., Amphora ovalis and Cymbella spp. Heterotrophic bacteria reached a maximum of $2.410^{7}$ cells $/ \mathrm{ml}$ and a minimum of $2.210^{6} \mathrm{cells} / \mathrm{ml}$, ten/fold more than typical marine concentrations and similar to those of freshwater systems. Episodic blooms of Dunaliella spp. (up to $1500 \mathrm{cells} / \mathrm{ml}$ ) were occasionally detected under summer conditions. The flow cytometry analysis showed two bacterial populations characterized by the DNA content (low and high DNA populations). Similar results have been related to the existence of two functional groups and to different metabolic activity (Gasol et al., 2000). The size abundance spectrum shows a non-linear behaviour characterized by discontinuities between bacteria and phytoplankton community (Fig. 3) (Galotti et al., in press). 


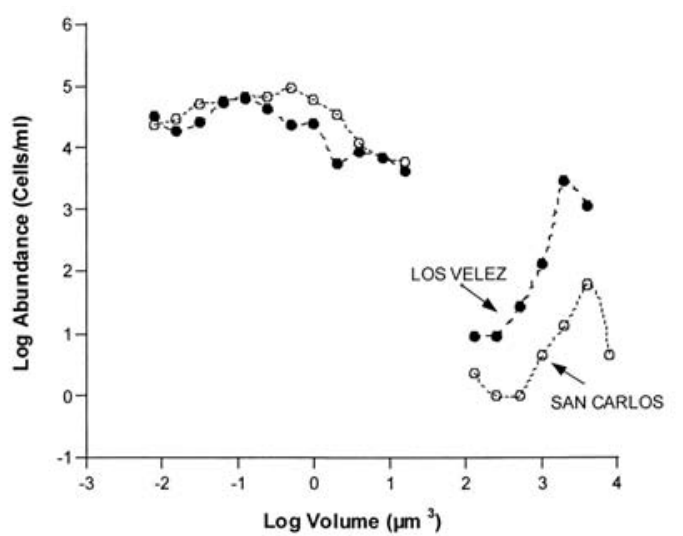

Figure 3. Size abundance spectrum of the pico and nanoplankton community of two Alto Guadalquivir salinas (San Carlos and Los Vélez) (modified from Galotti et al., in press). Espectro de abundancia de la comunidad de pico y nanoplancton en dos salinas del Alto Guadalquivir (San Carlos y Los Vélez) (modificado de Galotti et al., en prensa).

\section{OTHER FAUNA GROUPS}

\section{Invertebrates: Coleoptera}

The invertebrate communities of hypersaline environments are of interest for fauna studies. The most interesting species is the endemic hydraenidae coleopteran Ochthebius glaber (Montes \& Soler, 1988), which coexists in the studied area with other congeneric species such as $O$. notabilis, O. delgadoi, O. corrugatus, O. quadrifossulatus, $O$. andalusiacus and $O$. dentifer (Andrés Millán, personal communication, 2002). O. glaber is usually associated with hypersaline waters in the arid lands southeast of the Iberian Peninsula in the provinces of Córdoba, Jaén, Murcia and Albacete (Castro, 1997; Montes \& Soler, 1998; Millán et al., 2002). We analysed the presence of this species in 35 inland salinas of the Alto Guadalquivir region and the results showed that $O$. glaber was present in $80 \%$ of them, with maximum abundances during the summer-autumn period. Therefore, the conservation of wetlands and more specifically of inland salinas has special relevance in the protection of this endemic beetle.

\section{Waterbirds}

The Alto Guadalquivir wetlands are important sites for migratory waterfowl and shorebirds because it is located in a region where water is scarce in summer. We studied waterbirds over a period of eight years and registered a total of 71 species (see Ortega et al., 2004b; Ortega et al., 2005). The most common species were Tachybaptus ruficollis, Ardea cinerea, Anas platyrhynchos, Anas strepera, Aythia ferina, Gallinula chloropus and Fulica atra. The data obtained shows a total of 18 breeding, 17 wintering, 25 passing, and 11 resident bird species, which mainly use natural wetland and irrigation ponds. From these, twenty-seven species are included in the Red Data Book of Spanish Vertebrate (Blanco \& González, 1992) and twenty-nine in the Red Data Book of Endangered Vertebrates of Andalusia (Franco \& Rodríguez de los Santos, 2001). From the latter, 5 are catalogued as critically endangered species (CR: Ardeola ralloides, Marmaronetta angustirostris, Aythia nyroca, Fulica cristata and Chlidonias niger), 3 as endangered (EN), 7 as vulnerable (VU), and 14 species as near threatened (NT) or with deficient data (DD). Lastly, a total of 25 species are also included in Annex I of the Bird Directive 79/409/EEC. It is important to note the presence of the species Fulica cristata, which constitute the first site record in the region, and was part of a recent introduction programme in this area of Andalusia. This project permits the introduction of an incipient colony during the breeding season in the Alto Guadalquivir region, which has lead to the local reproduction of this species with a total of 40 and 34 flying chicks in 2004 and 2005, respectively (Ortega et al., unpublished data).

Finally, we also analysed the movements of greater flamingos Phoenicopterus ruber in order to discover its dispersal routes along the Alto Guadalquivir wetlands. Greater flamingos move among wetlands and therefore, the connectivity between the breeding site and foraging sites may be an important determinant of wetland use (Amat et al., 2005). Our results using readings of bird rings seem to confirm that this species use the Alto Guadalquivir wetlands in their foraging and dispersal movements (Ortega, unpublished data). 


\section{IMPACT ACTIVITIES: AGRICULTURAL PRACTICES}

Regular procedures in agriculture generate unquestionable environmental impacts (Vitousek et al., 1997; Guerrero et al., 2002, 2005). Some of these impacts are related to a decrease in water quality, owing to the use of toxic products such as herbicides, fungicides or pesticides, which induce changes in ecological characteristics. In recent years, ecotoxicological studies have substantially increased in order to measure the ecological effect of agricultural pollution on aquatic ecosystems (Van Dam et al., 1998). The results obtained could be useful in catchment management plans in areas where a specific pesticide is used. Therefore, an important area of interest in research is how intensive agriculture practices affect the ecological functions and values of the Alto Guadalquivir wetlands, especially on the tolerance response of different species to pesticides. Ecotoxicological test, used to predict levels of contaminants that will cause minimal harm to the aquatic environment, have been carried out in the laboratory using aquatic species representative of these wetland ecosystems. The toxicological tests have been developed not only to assess the lethal effect but also the sublethal effects that could represent a more realistic view of the consequences of pesticide use. The chosen species were Arctodiaptomus salinus (Copepoda: Calanoida) and the amphibians Bufo calamita and Rana perezi (Amphibia: Anura).

The copepod experiments were carried out with adult females and egg sacs, while the amphibian experiments were performed with eggs and tadpoles. Two different toxic substances extensively used in olive cultivation, dimetoate and copper, were used in the toxicological tests. The results obtained in the toxicological tests show that adult females, nauplii, egg sacs of the calanoid copepod, and amphibian larvae were all negatively affected by exposition to copper and dimetoate.

The lethal concentration obtained for adult copepods (24-h $\mathrm{LC}_{50}$ ) was rather lower than the regular dose of pesticide used in olive agriculture, with values between $0.82-1.37 \mathrm{mg} \mathrm{Cu} / \mathrm{l}$ and 3.30 -
$4.15 \mathrm{mg}$ dimetoate $/ 1$. These results also reflect the negative effect on Arctodiaptomus salinus secondary production as a consequence of an increase in females and nauplii mortality and by a reduction in hatching rate (Parra et al., 2005).

Amphibians have been widely advocated as excellent biological indicators of environmental health, because they are particularly vulnerable to environmental change (Wake, 1991). The results obtained show that amphibian populations are sensitive to pesticides during embryonic and larval development in aquatic habitats. Copper exposure affects growth with an increase in development time and mortality; therefore the use of this pesticide in agriculture has also a negative effect on the maintenance of amphibian populations in wetlands. The $\mathrm{LC}_{50}$ values obtained after $96-\mathrm{h}$ were between 0.17-0.32 and 0.34-0.39 mg Cu/l for Bufo calamita and Rana perezi, respectively (GarcíaMuñoz, unpublished data). We also detected important epithelia damages in both species, which probably affect osmotic equilibrium, energy expenditure, and lead to a decrease in the activity of the immune system. A comparative sensitivity test between both species performed at $0.3 \mathrm{mg} \mathrm{Cu} / 1$, showed a different tolerance level, with a survival percentage at $96-\mathrm{h}$ of $80 \%$ and $23 \%$ in Rana perezi and Bufo calamita, respectively. This implies a different resistance to copper, Rana perezi being more tolerant to pollution. Therefore, the legal restrictions in copper use must take into account the most sensitive species in order to protect a wider range of species in the community.

\section{CONSERVATION PLANS}

The demand for increased agricultural production in the Alto Guadalquivir region implies an intensive overexploitation on the water resources, which in combination with other factors has been the major cause of the loss of wetlands. This situation could be reversed and in this sense, the Andalusian government is operating a programme of wetland management and conservation (Andalusian Wetlands Plan). The plan defines the 
environmental policy on wetland matters in order to conserve the integrity of the ecosystem, promoting its use and preserving, now and for the future, their ecological, socio-economical, and historical-cultural functions (VV.AA., 2002). Although a total of 147 wetlands are inventoried in this plan, only 9 wetlands of the Alto Guadalquivir region are included. Furthermore, in the framework of preservation in Andalusia, only four of these wetlands are currently protected areas (Laguna Honda, Chinche, Conde and Grande), and the first three are also included on the Ramsar List of Wetlands of International Importance. Despite this lack of attention, these ecosystems are significant components of the Andalusian natural environment, and urgent conservation priorities are necessary.

One of the first steps essential for the protection and conservation of wetlands is the recognition of their values. The results obtained by our research group in relation to the high ornithological and floral community values, and the use of the Habitat Directive on the presence of rare species, allow us to propose a list of another nineteen wetlands. Together with the ones mentioned above, these areas must be included as Important Bird Areas (I.B.A.), and Sites of Community Importance (S.C.I.), and constitute the proposal of the wetland network "Lagunas del Alto Guadalquivir”' (Ortega et al., 2004b). The preservation of this wetland complex along the Guadalquivir River is very important at the regional level, not only for the population of migratory waterbirds, but also to allow for the biotic connection among wetlands, which contributes to the migration of other aquatic species and to the maintenance of local aquatic biodiversity.

We also have analysed the spatial relationships between wetlands and the public network of livestock paths in the province of Jaén (Madero et al., 2004). Our focus was to assess possible benefits for wetland conservation that might arise from the introduction of environmental criteria in defining wetland restoration priorities within the program that the Andalusian government is carrying out for the recovery of an effective public ownership of the livestock paths.
In addition, we have evaluated the land use in the catchment areas of natural wetlands. The results show that agriculture is the most important land use in the region (Ortega et al., in press). We recognize that there is a growing conflict between agricultural development and conservation in Spain, especially in the Alto Guadalquivir region, as a consequence of the intense growth of olive cultivation. A crucial aspect of this problem is the adverse effect on aquatic communities of the generalised use of pesticides, fungicides, and herbicides in wetland catchment areas that can enter the aquatic ecosystem via point or nonpoint sources. Consequently, laboratory toxicity tests are necessary to permit the regulation and enforcement of the legislation, which takes into account the most sensitive species. However, tolerance response tests cannot be easily used as tools for the evaluation of the state of a wetland. Thus, it is necessary to look for other methods that can provide quick and efficient information relating to the effects of pesticides on these ecosystems. The use of biomarkers that reflect subcellular or cellular responses can give us this information. These studies are of special interest in applied limnological research because the identification of biomarkers could be used to assess the toxic effects on wetland biota, and applied to the management of the ecosystem. Our future goals will be focused on the study of these biomarkers and the application of ecological models based on individuals (Grim \& Railsback, 2005), in order to determine the relationships between individual traits and system dynamics in order to understand the ecosystems and be able to protect them right now. Only if agricultural development is balanced by environmental considerations can an effective restoration of the majority of wetlands in this region be successful.

\section{ACKNOWLEDGEMENTS}

This work was supported by the Comisión Interministerial de Ciencia y Tecnología (CICYT Projects PB98-0307 and REN2001-3441C0201). We would like to thank Adel el Amran for his help with phytoplankton identification. 


\section{BIBLIOGRAPHY}

AMAT, J. A., M. A. RENDÓN, M. RENDÓN-MARTOS, A. GARRIDO \& J. M. RAMÍREZ. 2005. Ranking behaviour of greater flamingos during the breeding and post-breeding periods: linking connectivity to biological processes. Biological Conservation, 125: 183-192.

AMEZAGA, J. M., L. SANTAMARÍA \& A. J. GREEN. 2002. Biotic wetland connectivity - supporting a new approach for wetland policy. Acta Oecologica, 23: 213-222.

BAÑARES, A., G. BLANCA, J. GÜEMES, J. C. MORENO-SÁIZ \& S. ORTIZ. 2003. Atlas y Libro Rojo de la Flora Vascular Amenazada de España. Madrid: Dirección General de Conservación de la Naturaleza.1067 pp

BLANCA, G., B. CABEZUDO, J. E. HERNÁNDEZBERMEJO, C. M. HERRERA, J. MUÑOZ \& B. VALDÉS. 2000. Libro Rojo de la Flora Silvestre Amenazada de Andalucía. Tomo II: Especies Vulnerables. Sevilla: Junta de Andalucía. 375 pp.

BLANCO, J. C. \& J. L. GONZÁLEZ. 1992. Libro rojo de los vertebrados de España. Madrid: ICONA. $714 \mathrm{pp}$.

BRINSON, M. M. \& A. I. MÁLVAREZ. 2002. Temperate freshwater wetlands: types, status, and threats. Environmental Conservation, 29: 115-133.

CABEZUDO, B., S. TALAVERA, G. BLANCA, C. SALAZAR, M. CUETO, B. VALDÉS, J. E. HERNÁNDEZ-BERMEJO, C. M. HERRERA, C. RODRÍGUEZ-HIRALDO \& D. NAVAS. 2005. Lista roja de la flora vascular de Andalucía. Sevilla: Junta de Andalucía. 126 pp.

CASADO, S. \& C. MONTES. 1995. Guía de los lagos y humedales de España. Madrid: J. M. Reyero. 255 pp.

CASTRO, A. 1997. Coleópteros acuáticos del sur de Córdoba (España) (Haliplidae, Gyrinidae, Noteridae, Dytiscidae, Hydraenidae, Hydrochidae, Helophoridae, Hydrophilidae, Dryopidae y Elmidae). Zoologia Baetica, 8: 49-64.

CASTRO, M. C. 2004. Caracterización limnológica $y$ variabilidad temporal de la comunidad planctónica en laguna Honda (Jaén). Ph. D. Universidad de Jaén. 164 pp.

CASTRO, M. C., M. RIVERA, M. CRESPO, J. M. MARTÍN-GARCÍA \& F. GUERRERO. 2003. Morphological and sedimentological characterization of Honda temporary lake (southern Spain). Limnetica, 22: 147-154.
FINLAYSON, C. M., N. C. DAVIDSON, A. G. SPIERS \& N. J. STEVENSON. 1999. Global wetland inventory - current status and future priorities. Marine and Freshwater Research, 50: 717727.

FRANCO, A. \& M. RODRÍGUEZ DE LOS SANTOS, M. (coord.). 2001. Libro rojo de los vertebrados amenazados de Andalucía. Sevilla: Junta de Andalucía. 336 pp.

GALOTTI, A., F. JIMÉNEZ-GÓMEZ \& F. GUERRERO. In press. Estructura de tamaños de las comunidades microbianas en sistemas acuáticos salinos del Alto Guadalquivir. Limnetica.

GARCÍA, C. M. \& F. X. NIELL 1993. Seasonal change in a saline temporary lake (Fuente de Piedra, southern Spain). Hydrobiologia, 267: 211-223.

GARCÍA-FUENTES, A., C. SALAZAR, J. A. TORRES, E. CANO \& F. VALLE. 2001. Review of communities of Lygeum spartum L. in the south-eastern Iberian Peninsula (western Mediterranean). Journal of Arid Environments, 48: 323-339.

GASOL, J. M. \& P. A. DEL GIORGIO. 2000. Using flow cytometry for counting natural planktonic bacteria and understanding structure of planktonic bacterial communities. Scientia Marina, 64: 197224.

GRIMM, V. \& S. F. RAILSBACK. 2005. Individualbased modelling and ecology. New Jersey: Princenton University Press. 480 pp.

GUERRERO, F. \& M. C. CASTRO. 1997. Chlorophyll-a of size-fractionated phytoplankton at a temporary hypesaline lake. International Journal of Salt Lake Research, 5: 253-260.

GUERRERO, F., F. ORTEGA, G. PARRA, E. CANO, A. CANO, R. GARCÍA-RUIZ \& J. A. CARREIRA. 2002. Efectos ecológicos de la intensificación del cultivo del olivar en la comarca del Alto Guadalquivir: repercusiones sobre la diversidad. In: La cultura del aceite en Andalucía. La tradición frente a la modernidad. J. L. Anta y J. Palacios (eds.): 53-63. Sevilla: Fundación Machado.

GUERRERO, F., F. ORTEGA \& J. L. ANTA. 2004. Las salinas de la provincia de Jaén. In: Salinas de Andalucía. A. Pérez Hurtado (coord.): 127-131. Sevilla: Junta de Andalucía.

GUERRERO, F., G. PARRA, F. JIMÉNEZ-GÓMEZ, M. C. CASTRO, R. JIMÉNEZ-MELERO, A. GALOTTI \& F. ORTEGA. 2005. Los ecosistemas acuáticos en el contexto de los agrosistemas: la comarca del Alto Guadalquivir. In: La cultura del 
olivo: ecología, economía, sociedad. J. L. Anta, J. Palacios y F. Guerrero (eds.): 381-402. Jaén: Universidad de Jaén.

HOLLIS, G. E. 1995. Wetlands and river restoration in Europe and the Mediterranean. In: Bases ecológicas para la restauración de humedales en la cuenca Mediterránea. C. Montes, G. Oliver, F. Molina y J. Cobos (eds.): 125-142. Sevilla. Junta de Andalucía.

LÓPEZ-GONZÁlEZ, P., F. GUERRERO \& M. C. CASTRO. 1998. Seasonal fluctuations in the plankton community in a hypersaline temporary lake (Honda, southern Spain). International Journal of Salt Lake Research, 6: 353-371.

MADERO, A., F. ORTEGA \& F. GUERRERO. 2004. Lagunas y vías pecuarias en la provincia de Jaén: una nueva oportunidad para la conservación de los humedales. In: Biología de la Conservación. Reflexiones, propuestas y estudios desde el SE ibérico. J. Peñas de Giles y L. Gutiérrez Cantero (eds.): 277-288. Almería: Instituto de Estudios Almerienses.

MILLÁN, A., J. L. MORENO \& J. VELASCO. 2002. Los coleópteros y heterópteros acuáticos y semiacuáticos de la provincia de Albacete: catálogo faunístico y estudio ecológico. Albacete: Instituto de Estudios Albacetenses. 180 pp.

MITSCH, W. J. \& J. G. GOSSELINK. 2000. Wetlands. New York: John Wiley \& Sons. 920 pp.

MOLINA, F., C. MONTES, E. GONZÁLEZ-CAPITEL \& J. C. RUBIO. 2002. El plan andaluz de humedales. Una estrategia para la conservación de los humedales en el siglo XXI. Medioambiente, 39: 14-19.

MONTES, C. \& A. G. SOLER. 1998. A new species of the genus Ochthebius (subgenus Calobius) (Coleoptera:Hydraenidae) from Iberian hypersaline waters. Aquatic Insects, 10: 43-47.

NAVEH, Z. \& A. LIEBERMAN. 1994. Landscape ecology: theory and application. New York: Springer-Verlag. $360 \mathrm{pp}$.

ORTEGA, F., M. C. CASTRO, G. PARRA, M. CONRADI \& F. GUERRERO. 2001. Vegetación de las lagunas endorreicas del Alto Guadalquivir. El complejo lagunar de Martos. In: Valoración y gestión de espacios naturales. E. Cano, A. GarcíaFuentes, J. A. Torres-Cordero y C. Salazar (eds.): 229-240. Universidad de Jaén, Jaén.

ORTEGA, F., G. PARRA \& F. GUERRERO. 2003. Los humedales del Alto Guadalquivir: inventario, tipologías y estado de conservación. In: Ecología, manejo y conservación de los humedales. M.
Paracuellos (ed.): 113-123. Almería. Instituto de Estudios Almerienses.

ORTEGA, F. \& F. GUERRERO. 2003. Vegetación de las lagunas y humedales del Alto Guadalquivir. El complejo lagunar de Alcaudete-Valenzuela. In: In memoriam al Prof. Dr. Isidoro Ruiz Martínez. J. M. Pérez-Jiménez (ed.): 101-116. Universidad de Jaén, Jaén.

ORTEGA, F., M. PARACUELLOS \& F. GUERRERO. 2004a. Corología de macrófitos acuáticos en Andalucía oriental. Lazaroa, 25: 179-185.

ORTEGA, F., G. PARRA \& F. GUERRERO. 2004b. Las lagunas del Alto Guadalquivir: propuestas para su protección y conservación. In: Congreso de Restauración de ríos y humedales. J. Cachón y T. López-Piñeiro (eds.): 131-142. Madrid: Cedex.

ORTEGA, F., A. MADERO \& F. GUERRERO. 2005. Las balsas de riego para el olivar: una alternativa a la destrucción de humedales. In: La cultura del olivo: ecología, economía, sociedad. J. L. Anta, J. Palacios y F. Guerrero (eds.): 435-448. Universidad de Jaén, Jaén.

ORTEGA, F., G. PARRA \& F. GUERRERO. In press. Usos del suelo en las cuencas hidrográficas de los humedales del Alto Guadalquivir: importancia de una adecuada gestión. Limnetica.

PARRA, G., R. JIMÉNEZ-MELERO \& F. GUERRERO. 2005. Agricultural impacts on Mediterranean wetlands: the effect of pesticides on survival and hatching rates in copepods. International Journal of Limnology, 41 (3): 161167.

PLATT, T. 1989. Flow cytometry in oceanography. In: Cytometry in aquatic sciences. C. M. Yentsch. and P. K. Hora (eds.): 500. Cytometry, 10.

POR, F. D. 1980. A classification of hypersaline waters, based on trophic criteria. Marine Ecology, 1: 121-131.

QUESADA, T. 1996. Las salinas de interior de Andalucía oriental: ensayo de tipología. In: Agricultura y regadio en Al-Andalus: síntesis y problemas. L. Cara y A. Malpica (eds.): 317-333. Almería: Instituto de Estudios Almerienses.

SALAZAR, C., A. GARCÍA-FUENTES, F. ORTEGA \& F. GUERRERO. 2003. Pastizales terofíticos halófilos de las explotaciones salineras del Alto Guadalquivir: caracterización fitosociológica y conservación. In: Pastos, desarrollo y conservación. A. B. Robles, M. E. Ramos, M. C. Morales, E. de Simón, J. L. González y J. Boza (eds.): 571576. Sevilla: Junta de Andalucía. 
VAN DAM, R. A., C. CAMILLERI \& C. M. FINLAYSON. 1998. The potential of rapid assessment techniques as early warming indicators of wetland degradation: a review. Environmental Toxicology and Water Quality, 13: 297-312.

VITOUSEK, P. M., J. D. ABER, R. W. HOWART, G. E. LIKENS, P. A, MATSON, D. W. SCHINDLER, W. H. SCHLESINGER \& D. G. TILMAN. 1997. Human alteration of the global nitrogen cycle: sources and consequences. Ecological Applications, 7: 737-750.
VV.AA. 2000. Lista roja de la flora vascular española (valoración según categorías UICN). Conservación Vegetal, 6 (extra): 11-38.

VV.AA. 2002. Plan Andaluz de Humedales. Sevilla: Junta de Andalucía. 253 pp.

WAKE, D. B. 1991. Declining amphibian populations. Science, 253: 860.

WILLIAMS, W. D. 1999. Conservation of wetlands in drylands: a key global issue. Aquatic Conservation: Marine and Freshwater Ecosystems, 9: 517-522. 